\title{
Review: \\ A relation between ethnobotany and bioprospecting of edible flower Butterfly Pea (Clitoria ternatea) in Indonesia
}

\author{
WHISNU FEBRY AFRIANTO ${ }^{1, \boldsymbol{v}}$, FADILA TAMNGE ${ }^{2}$, LAELI NUR HASANAH ${ }^{3}$ \\ 'Ecosystem and Biodiversity (Ecosbio). Jl. Merapi 02/01, Datengan, Grogol, Kediri 64151, East Java, Indonesia, •email: whisnu.afrianto@apps.ipb.ac.id \\ ${ }^{2}$ Departement of Animal Husbandry, Universitas Khairun. Jl. Raya Gambesi, Kampus II Unkhair, Ternate, North Maluku, Indonesia \\ ${ }^{3}$ Departement of Nutrition, Faculty of Science and Technology, Universitas PGRI Yogyakarta. Jl. IKIP PGRI I Sonosewu No.117, Bantul 55184, \\ Yogyakarta, Indonesia
}

Manuscript received: 11 April 2020. Revision accepted: 13 October 2020.

\begin{abstract}
Afrianto WF, Tamnge F, Hasanah LN. 2020. Review: A relation between ethnobotany and bioprospecting of edible flower Butterfly Pea (Clitoria ternatea) in Indonesia. Asian J Ethnobiol 3: 51-61. Clitoria ternatea L., known as "bunga telang" in Indonesia, is an important medicinal plant to Fabaceae, an ornamental perennial climber. It has widely distributed throughout Africa, Asia, Australia, North and South America, Pacific (Northwestern, South-Central, and Southwestern). This review aims to study the relation between ethnobotany and bioprospecting of $C$. ternatea. The literature study revealed that Indonesian communities use flowers as part of $C$. ternatea as an eye medicine, boils disease, an ornamental plant, and a symbol in traditional ceremonies. Leaf, flower, seed, and root of this species have bioprospecting for medicine, agriculture, and food and beverage. Ethnobiology exploration of $C$. ternatea in Indonesia is an initial step to observe the bioprospecting potential. Then, further research can continue to produce commercial products that will provide an economic impact and motivate communities to take part in conservation actions. The present study assesses the minor works on bioecology, ethnobotany, bioprospecting, and market potential. We hope that the study's output can spur further research and industry approach.
\end{abstract}

Keywords: Bioprospecting, Clitoria ternatea, ethnobotany, Fabaceae, medicinal plant

\section{INTRODUCTION}

Clitoria ternatea L. is known as "bunga telang" in Indonesia. This wild plant belongs to the plant of the Fabaceae family (Karel et al. 2018). The origin of $C$. ternatea is still debatable, but some studies mentioned that C. ternatea is a native plant of Ternate, Indonesia Archipelago (Jain et al. 2003; Gupta et al. 2010; Oguis et al. 2019). The etymology of this species is postulated to be from the Ternate Island in the Indonesian archipelago. It is based on the specific description of Linnaeus produced (Oguis et al., 2019). Furthermore, according to Staples (1992), C. ternatea originated from the Pacific Ocean or the South China Sea, but it is from around the Indian Ocean. Currently, $C$. ternatea has widely distributed throughout Africa, Asia, Australia, North and South America, Pacific (Northwestern, South-Central, and Southwestern) (Al-Snafi 2016).

Clitoria ternatea is an ornamental perennial climber in other plants or in-wall of home gardens, which lives in various types of soil and has a pH of 5.5-8.9 (Sutedi 2013; Chen et al. 2018). It can adapt to heavy cracking clay soil areas (Hall 1985). C. ternatea is a self-pollination plant, and it spreads through seed (Chen et al. 2018). C. ternatea occurs in plentiful sunlight and is partially shaded (Jamil et al., 2018). Dry stressing can inhibit population growth, fresh weight, germination, shoot, and root length (Bharti and Kumari 2017). This medicinal plant can be found in high rainfall areas and prolonged dry season areas (Gomez and Kalamani 2003). The germination is 1-2 weeks, and the flowering is 3-4 weeks (Jamil et al. 2018).

The height of $C$. ternatea is up to $6 \mathrm{~m}$ with soft twigs. The description steam of $C$. ternatea is adpressed pubescent, glabrescent, and slender. $C$. ternatea has imparipinnate leaves consisting of 5-7 elliptic to lanceolate leaflets with a length of 1-6.7 cm and wide of $0.3-4 \mathrm{~cm}$. The petiole length is $1-3 \mathrm{~cm}$; the rachis is $1-6 \mathrm{~cm}$, petiolules 1-3 mm, and leaflets 4-10 mm. The flower characteristics are axillary, paired, or solitary, with pedicels length of 6-9 mm, and striking blue and white color. The color of the seeds is black and brown, with a length of 4.5$7 \mathrm{~mm}$, wide of 3-4 mm, and thick of 2-2.5 mm. The calyx is pubescent with tube $8-12 \mathrm{~mm}$, under one-third of their length with the upper pair, acuminate or acute. The corolla is standard white, often margined with completely blue or blue. The pod is flat with a length of $6-12.5 \mathrm{~cm}$ and wide 0.7-1.2 cm; on each pod, there are 6-8 seeds. The color of the seeds is black and brown, with a length of 4.5-7 mm, wide of 3-4 mm, and thick of 2-2.5 mm (Gillett et al. 1971).

Leaves and flowers have flavonols compounds (Kazuma et al. 2003a,b). The other non-proteinaceous components were found in the roots of $C$. ternatea. For instance, taraxerol, novel norneolignans, and clitorienolactones A-C were found in the roots (Vasisht et al., 2016). C. ternatea has cyclotides (proteinaceous components) and is the only family member within the 
Fabaceae (Gilding et al., 2015). The edible flowers had antioxidant activity and antimicrobial potential as a medicinal plant for several diseases (Petrova et al. 2016; Dhiman et al. 2017; Wang et al. 2017).

Ethnobotany of $C$. ternatea has been documented as the drug "Sankhupushpi" of Ayurveda (Mukherjee et al., 2008). Ayurveda means the science about life; it contains the traditional medicinal knowledge in India from between 2500 and 500 B.C (Mukherjee and Wahile 2006). The seeds and roots are used for alterative, laxative, and a 'tonic of the nerves' (Mukherjee et al., 2008). On the other hand, the data of ethnobotany in Indonesia is still limited. In Indonesia, C. ternatea is used as a medicinal plant or for traditional ceremonies and is known locally only.

Bioprospecting is an exploration of new natural resources of economic and social value. The pharmaceutical industry is one of the massive industries conducting it. However, other sectors, such as agriculture, construction, manufacturing, engineering, and others, also explore bioprospecting (Beattie et al., 2005). To find a novel of biological and chemical resources was conducted by exploration in nature or from traditional knowledge. Thus, the ethnobotany of species is crucial as foundation information for bioprospecting. Based on that, benefits from species can be used wider and optimal. This current literature review aims to study the relation between ethnobotany and bioprospecting of $C$. ternatea. The data documented of ethnobotany and bioprospecting from $C$. ternatea is to develop conservation action and optimize utilization

\section{ETHNOBOTANY OF CLITORIA TERNATEA}

Numerous ethnobotany research of $C$. ternatea is preliminary and requires a more thorough investigation. In Indonesia, research areas are still limited, such as East Java, Bali, West Nusa Tenggara, West Kalimantan, and Central Sulawesi. In Java, for instance, the data was only found in Madura. Ethnobotany knowledge of C. ternatea was depicted in Table 1.

The exploration of the ethnobotany of $C$. ternatea in Tamao Village did not reveal clear information about the utilization (Haryanti et al., 2015). However, based on literature, Dayak Tamambaloh in Embaloh Hulu is still keeping their local wisdom (Sulistiyowati 2016). In general, the Dayak Tamambaloh Community finds beneficial plants from forests, house yards, gardens, river beaches, hills, and fields (Rike et al., 2018; Supiandi and Leliavia 2019).

Table 1. List of ethnobotany research of Clitoria ternatea in Indonesia

\begin{tabular}{|c|c|c|c|}
\hline Location & Part & Utilization & References \\
\hline $\begin{array}{l}\text { Tamao Village, Embaloh Hulu District, } \\
\text { West Kalimantan }\end{array}$ & Flowers & $\begin{array}{l}\text { Medicine, traditional } \\
\text { ceremony, and ornamental }\end{array}$ & Haryanti et al. (2015) \\
\hline $\begin{array}{l}\text { Five of Pakraman Villages, Bali } \\
\text { (Pakraman Jatiluwih Tabanan, Pakraman } \\
\text { Sukawati Gianyar, Pakraman Penglipuran } \\
\text { Bangli, Pakraman Tenganan Karangasem, } \\
\text { and Pakraman Banyuning Buleleng) }\end{array}$ & Flowers & $\begin{array}{l}\text { Traditional ceremony } \\
\text { (Panca Yadnya) }\end{array}$ & Surata et al. (2015) \\
\hline $\begin{array}{l}\text { Lenteng District, Guluk-Guluk District, and } \\
\text { Bluto District in Sumenep Regency. }\end{array}$ & Flowers & Eye disease medicine & Destryana and Ismawati (2019) \\
\hline $\begin{array}{l}\text { The Hindu Community of Jagaraga } \\
\text { Village, West Lombok Regency, West } \\
\text { Nusa Tenggara }\end{array}$ & Flowers & Eye disease medicine & Eni et al. (2019) \\
\hline $\begin{array}{l}\text { Togian Tribe, Tojo Una-Una, Central } \\
\text { Sulawesi }\end{array}$ & Flowers and roots & Boils and fever medicine & Tabeo et al. (2019) \\
\hline $\begin{array}{l}\text { The Adjacent Area of Lake Buyan- } \\
\text { Tamblingan, Bali }\end{array}$ & Flowers & Eye disease medicine & Oktavia et al. (2019) \\
\hline Mincidan Village, Klungkung, Bali & Flowers & $\begin{array}{l}\text { Eye disease medicine, } \\
\text { 'nunas' tirta ceremony, and } \\
\text { ornamental }\end{array}$ & Defiani and Kriswiyanti (2019) \\
\hline Madura Sumenep Communities & Flowers & Clean and clear baby's eyes & Ismawati and Destryana (2019) \\
\hline
\end{tabular}


The ethnobotany from some areas in Indonesia used the flowers for many purposes. Flower of $C$. ternatea is utilized as the medicine for eye diseases by the SumenepMadura community (Ismawati and Destryana 2019), the adjacent area of Lake Buyan-Tamblingan, Bali (Oktavia et al. 2019), the community around the area model of KPH Kapuas Upstream (Haryanti et al. 2015), as well as the Hindu Community of Jagaraga Village, West Lombok Regency, West Nusa Tenggara (Eni et al. 2019). Ethnobotany knowledge of $C$. ternatea for eyes medicine has been proven through research. The phenol $0.026 \%$ from the extracts of $C$. ternatea flower revealed inhibition of $0.87 \mathrm{~mm}$ as an antibacterial of Staphylococcus aureus, a bacterium that causes eyes diseases (Hutajulu et al. 2008). Through ultrafiltration (UF), the extracts of $C$. ternatea in water extract sterilization can be used to eye drops ingredients (Anthika et al., 2015). Furthermore, the extracts of $C$. ternatea can dissolve Calcium (Ca) and Natrium $(\mathrm{Na})$ compiler cataract model in the concentration of $2.5 \%$ (Kusrini et al. 2017).

Togian tribal communities in Malenge Island, Talatako District, Tojo Una-Una, Central Sulawesi used C. ternatea for boils medicine (Tabeo et al. 2019). Boils are also caused by $S$. aureus. The antibiotic of S. aureus can be produced from ultrasound-assisted aqueous leaf and petal extract, ethanolic leaf, and callus extract of $C$. ternatea (Shahid et al. 2009; Anthika et al. 2015). In addition, $C$. tertanea also has an antipyretic activity that can reduce fever (Devi et al., 2003).

The various ceremonies which belong to the Panca Yadnya ceremony need part of plants for the ceremony, and C. ternatea is one of them (Surata et al. 2015; Defiani and Kriswiyanti 2019). Hindu Bali's people use leaves, flowers, and fruits as a medium of offering (sesajen) and praying (persembahyangan) (Sardiana and Dinata 2010). Furthermore, they classified into several uses such as canang (offering to God), kewangen (scenting God's name), and bhasma (the symbol of Siwa's purity) (Surata et al., 2015).

C. ternatea is also used as an ornamental plant. Since $C$. ternatea has an attractive color for making aesthetic scenery to home and garden and ornamental crop adding value (Karel et al. 2018). For example, Mincidan Village in Bali uses plant floral diversity to promote ecotourism (Defiani and Kriswiyanti 2019).

\section{BIOPROSPECTING}

Bioprospecting includes cultural information, biodiversity information, and processing and handling technology. Bioprospecting is the effort to search genes and natural compounds of biodiversity for product development (Pushpangadan et al. 2018). The economic benefits from $C$. ternatea include food and beverage, forage, phytochemicals, biopesticides, bioinsecticides, colorants, and medicines. In this part, we reviewed the evidence, based on scientific and research, the difference with the ethnobotany that only focused on Indonesia's studies. In bioprospecting, we explored the current research progress of $C$. ternatea from Indonesia. Thus, we can elaborate on evidence-based scientific and ethnobotany from Indonesia.

\section{Phytochemicals}

Leaf of $C$. ternatea contains compounds such as 3rutinoside, beta-sitosterol, 3 monoglucoside, 3-o-rhamnosylglucoside, 3-neohesperidoside, kaempferol-3-o-rhamnosyl essential oils (Tiwari and Gupta 1959; Morita et al. 1977; Mukherjee et al. 2008; Manjula et al. 2013; Thakur et al. 2018). The seed contains oleic, linoleic, stearic, betasitosterol, polypeptide, linolenic acids, a water-soluble mucilage, delphinidin 3, 3', 5'-tri-o-glucoside, palmitic, finotin, oligosaccharides, p-hydroxycinnamic acid (4), anthoxanthin glucoside, flavonol-3-glycoside, ethyl $\alpha$-dgalactopyranoside, adenosine, 3,5,7,4-tetrahydroxyflavone, 3-rhamnoglucoside, hexacosanol,-sitosterol (5),-sitosterol (Grindley et al. 1954; Kulshrestha and Khare 1967; Kulshrestha and Khare 1968; Joshi et al. 1981; Revilleza et al. 1990; Macedo and Xavier-Filho 1992; Husain and Devi 1998; Kelemu et al. 2004). Root has been reported containing alanine, aminobutyric acid, aspartic acid, arginine, flavonoids, glycine, histidine, leucine, methyleneglutamic acid, ornithine, saponins, phenols, taraxerone, taraxerol, valine (Banerjee and Chakravarti 1964; Rajagopalan 1964; Kumar et al. 2008; Swain et al. 2012; Manjula et al. 2013). The flower has ternatins, flavonoids, alkaloids, tannins, resins. (Kazuma et al. 2003 a,b; Kazuma et al. 2004; Manjula et al. 2013).

\section{Food and beverage use}

The flower of $C$. ternatea is used as a natural coloring for food and beverage. The bright blue color is the advantage characteristic of colors. The color is produced from anthocyanin in ternatins (Srivastava and Pande 1977; Zussiva et al. 2012). It is the pigment of the flavonoid group, which is soluble in water (Zussiva et al., 2012). For a natural dye of food and beverage, $C$. ternatea showed the best result in the anthocyanin with the treatment of the $10 \%$ addition maltodextrin concentration (Hariadi et al. 2018). The compound's content is stable and could withstand high temperatures (Azima et al., 2017; Angriani 2019). Coloring extracts flower was used to an ice lolly with the same quality with blue diamonds of $\mathrm{Cl} 42090$ (Hartono and Angelia 2013). It can also be coloring for several traditional foods such as putu, onde-onde, bandang, barangko, getuk lindri, cendol, candy, sticky rice tapai, and others (Saati et al. 2018; Angriani 2019; Febrianti 2019; Permana 2019; Palimbong and Pariama 2020; Shofi and Putri 2020). The flower extracts with $0.25 \%$ and $1 \%$ concentration were more stable when used in the paracetamol syrup preparations (Pratimasari and Lindawati 2018). Furthermore, C. ternatea was used for coloring goat milk yogurt, and it showed effects on the levels of pressure (color) (Dewi et al. 2019).

Blue tea from $C$. ternatea began to be known in Indonesia. It possesses antioxidant properties for healthy beverages because it reduces oxidative stress (Srichalkul 2018; Lakshan et al. 2019). Moreover, drinking C. ternatea can reduce postprandial glucose and insulin concentration 
concomitant (Chusak et al. 2018a). Processing of $C$. ternatea is conducted through drying, either using sunlight or an oven. Drying is one of the most critical steps in processing $C$. ternatea tea. The aims are to prolong shelf life, prevent microorganism growth, reduce weight to press storage and transport costs, and minimize enzymatic degradation (Fernandes et al. 2018). Drying is conducted at 08.00-12.00; then, it is continued on the next day. By doing so, the beneficial compounds of $C$. ternatea are not damaged by sunlight (Mulangsari 2019). C. ternatea tea is made with five flower petals $(1.0 \mathrm{~g})$ dissolved in $250 \mathrm{ml}$ boiling water. Consuming $C$. ternatea tea routinely is good for the thin phlegm in asthmatics (Kusuma 2019) and can improve human health due to its non-caffeinated contents (Panda 2018).

Starch digestibility of cooked rice with a rice cooker was reduced by the incorporation of $1.25 \%$ and $2.5 \%(\mathrm{w} / \mathrm{v})$ of $C$. ternatea flower extracted and $2.5 \%(\mathrm{w} / \mathrm{v})$ with a microwave oven (Chusak et al. 2019). Flower extracts of $C$. ternatea caused a reduction in hydrolysis index, predicted glycemic index of flour, and glucose released at $0.5 \%, 1 \%$, and $2 \%(\mathrm{w} / \mathrm{v})$. In comparison, 5\%, 10\%, and $20 \%(\mathrm{w} / \mathrm{w})$ decreased the rate of starch digestion of the wheat bread. The pancreatic $\alpha$-amylase activity can be inhibited by $1 \%$ and $2 \%(\mathrm{w} / \mathrm{v})$ by using a substrate of all flours (Chusak et al. 2018b). In addition, flower extracts of C. ternatea inhibited the food damage and disease of Pseudomonas aeruginosa (the extracted ethanol flower concentration of $10 \%$ to $100 \%$ ) and Bacillus cereus (the extracted ethanol flower concentration of $30 \%$ to $100 \%$.) (Riyanto et al 2019). These bacteria have been reported as the food poisoning cases in several foods such as rice and noodles in Indonesia's market, particularly in food streets (Ruriani and Nurhayati 2010; Amanati 2014; Ekantini et al. 2017). This makes $C$. ternatea use a bioactive potential for food preservation (Kamila et al., 2009).

\section{Agricultural applications} Anthelmintic

C. ternatea has Anthelmintic activity reported killing Meloidogyne incognita (Hasan and Jain 1985; Kumari and Devi 2013). The high effectivity to inhibition of hatching of the egg can be used to minimize the damage of $M$. incognita to fruits and leaves of mulberry. M. incognita has been reported decreasing in pepper production in Bangka and West Kalimantan (Sukanaya 2001). In soybean, $M$. incognita can make lost yield up to $30 \%-90 \%$ (Suryanti et al., 2017). M. incognita is also a critical plant disease on kenaf (Hibiscus cannabinus) production in the nursery and tomato development area (Budi et al. 2006; Pradana et al. 2016; Irmawatie et al. 2019).

\section{Antibacterial and antifungal}

The purification of $C$. ternatea seed produces a small protein called Finotin (Kelemu et al. 2004). Finotin has been reported to significantly kill the bacteria of Xanthomonas axonopodis, which attacks beans. $X$. axonopodis is a disease that causes severe damage in soybean crops and economic loss in citrus crops in
Indonesia (Das 2003; Khaeruni et al. 2007; Khaeruni et al. 2008).

As a fungicide, a protein that was designed as a $\mathrm{Ct}$ protein from the isolation of $C$. ternatea seed caused the death of some fungus, such as Alternaria sp., Aspergillus flavus, Cladosporium sp., Curvularia sp., Rhizopus sp., and Sclerotium sp. (Ajesh and Sreejith 2014). Finotin from $C$. ternatea seed could inhibit Bipolaris oryzae, Pyricularia grisea from rice, Colletotrichum gloeosporioides, and Lasiodiplodia theobromae from Stylosanthes spp; Colletotrichum lindemuthianum, Fusarium solani from common bean, and Rhizoctonia solani from Brachiaria spp (Kelemu et al. 2004). Furthermore, Fusarium oxysporum that causes moler disease on Shallot from Indonesia can be killed by the crude aqueous leaf extracts of $50 \%$ (Das and Chatterjee 2014) and flower extracts at 5\% concentration (Suganda and Adhi 2017). Research by Suganda and Adhi (2017) is preliminary for plant antifungals since the focus is mainly on human pathogens rather than plant pathogens.

\section{Insecticidal}

Cyclotide sequences have insecticidal activity against Helicoverpa armigera, the cotton budworm (Poth et al., 2011). H. amigera makes cotton fruit undeveloped and fallen because of broaching buds, flowers, and bolls, especially in central areas of cotton production in Indonesia such as Central Java, East Java, South Sulawesi, Southeast Sulawesi, East Nusa Tenggara, West Nusa Tenggara, and Bali (Diyasti et al. 2016). 1-2\% ( $\mathrm{vol} / \mathrm{vol})$ of the oil-based formulation of the $C$. ternatea mixture was used for integrated pest management (IPM) to control Helicoverpa spp in Australian cotton. Furthermore, $1 \% \mathrm{w} / \mathrm{w}$ finotin application to Zabrotes subfasciatus and $5 \% \mathrm{w} / \mathrm{w}$ to Acanthoscelides obtectus resulted in a maximum level of $100 \%$ larva mortality (Mensah et al. 2015).

\section{Forage for livestock}

To obtain high quality and nutrition, $C$. ternatea is harvested at 45 days (Mahala et al., 2012). C. ternatea has high productivity up to 17-25 tons/ha (Abdelhamid and Gabr 1993). A high carotenoid content positively impacts bovine livestock fertility and egg yolk color (Barro and Ribeiro 1983). C. ternatea also has a better potential nutritive value than alfalfa and clover (Abreu et al., 2014).

Clitoria ternatea escalates diets and sound quality for ruminants due to its nutritional contents (Gomez and Kalamani 2003; Avalos et al. 2004; Juma et al. 2006; Shamnad 2019). As a forage, $C$. ternate increases the weight of beef cattle and cows, 0.7 and $0.36 \mathrm{~kg} /$ day, respectively (Sutedi 2013). In addition, the weight loss of cows during shipment from Timor to Java can be minimized up to $5-7 \%$ when generally it is $12-15 \%$ (Nunik 2009).

Barros et al. (1991) discovered a better dietary $\mathrm{N}$ of goats given $C$. ternatea as forage. Guinea Grass-Clitoria mixed hay can be a potential forage to sheep because it increases digestible dry matter intake up to $61 \%$ (Sandoval et al. 2009). Besides that, the use of $C$. ternatea to sheep also provides a positive effect on wool growth and live weight gain (Schlink 1998). The two cuts of $C$. ternatea 
have better acid and neutral detergent fiber, acid detergent lignin cellulose, crude protein and fiber, hemicellulose than berseem hay (Abdelhamid and Gabr 1993).

A decrease of $10 \%$ of $C$. ternatea for boilers diet showed better growth (Marin et al., 2003). A comparison between $C$. ternatea and Brachiaria humidicola showed that $C$. ternatea has higher protein content and metabolizes energy, but the fiber content was lower than B. Humidicola. Nevertheless, $15 \%$ C. ternatea substitution decreased growth and consumption in chicken (Monforte et al. 2002).

Muir and Massaete (1996) found that the crude protein content of dietary components used during experiments in rabbits was $16 \%$. It is because $C$. ternatea has protein up to $18-25 \%$, which complies with the nutritional needs of rabbits (Sutedi 2013). Nevertheless, Elamin et al. (2011) suggested that sweet potato is better used for rabbits than C. ternatea based on performance and blood constituents.

\section{Soil fertility}

The high nodule maintenance and the non-structural carbohydrate mobilization make $C$. ternatea adapt quickly to stress after the shoot removal (De Souza et al. 1996). $C$. ternatea increases Nitrogen, Phosphor, Potassium, and Magnesium and impacts soil acidification and nutrient solubilization (Njunie et al. 2004; Alderete-Chavez et al. 2011). Environmental conditions affect nodulation growth. The optimum nodulation growth is on moderate temperatures, such as at $06.00\left(27-32^{\circ} \mathrm{C}\right), 14.00\left(36-42^{\circ} \mathrm{C}\right)$ and $18.00\left(27-30^{\circ} \mathrm{C}\right)$ and with the light intensity in summer (11.4-17.1 Wm-2) and winter (11.4 Wm-2), as well as the optimum duration of 11-14 hours (Habish and Mahdi 1979). On the other hand, an optimum soil pH was 6.3 in the four strains of C. ternatea (Zoroug and Munns 1980a). Phosphor is an essential nutrient for nodulation growth (Zoroug and Munns 1980b). Unfortunately, we currently do not find the $C$. ternatea to improve soil fertility in Indonesia. This can be an opportunity to discover the utilization of $C$. ternatea to improve soil fertility in Indonesia. It is because $C$. ternatea grows horizontally and makes tightly covered. This growth characteristic brings several benefits, such as preventing erosion, maintaining soil moisture, and improving soil fertility from leaves (Suarna 2005).

\section{Medicinal properties \\ Antimicrobial}

Cliotides T1-T2 in flower, seed, and root of C. ternatea can be used as an antimicrobial against Pseudomonas aeruginosa, Klebsiella pneumonia, and Escherichia coli (Nguyen et al. 2011). Fourth, novel cyclotide sequences have been identified, and noted that $C$. ternatea was one of the prosperous cyclotide-producing medicinal plants (Nguyen et al. 2016). Ethanolic and aqueous leaf and callus extracts can inhibit human diseases bacteria, such as Bacillus cereus, B. subtilis, Enterococcus faecalis, Staphylococcus aureus, S. epidermidis, Streptococcus pyogenes, and S. viridans (Shahid et al. 2009); Micrococcus luteus (Ajesh and Sreejith 2014); Salmonella typhi and Proteus Vulgaris (Anand et al. 2011). Moreover, as an antifungal, $14.3 \mathrm{kDa}$ seed protein inhibited
Aspergillus fumigatus, A. niger, Candida albicans, $C$. parapsilosis, Cryptococcus neoformans, C. albidus, and $C$. laurentii (Ajesh and Sreejith 2014). Leaf extracts successfully inhibited Aspergillus niger (Kamila et al. 2009). In ethnobotany, communities mostly use $C$. ternatea for diseases caused by microbes, such as eye disease and boils caused by $S$. aureus. There are numerous benefits from $C$. ternatea as an antimicrobial that Indonesian communities have not explored.

\section{Antidiabetic}

In Indonesia, it has 10,681,400 cases of diabetes in adults (International Diabetes Federation 2020). Currently, $C$. ternatea leaf extracts have shown potential for an antidiabetic medicine (Daisy and Rajathi 2009; Suganya et al. 2014; Talpae et al. 2014; Chusak et al. 2018b; Kavitha 2018). Leaf extracts of $C$. ternatea decrease blood glucose, HbA1c, other biochemical parameters and increase serum insulin level (Kavitha 2018). After five hours of oral administration, the mix of Punica granatum and the dried flower powder resulted in an antihyperglycemic effect. This is affected by flavonoids and alkaloids (Borikar et al., 2018). The root extract in experimental rat models, $C$. ternatea, prevented pancreatic tissue in juvenile diabetic and the possible complications related to brain hippocampal area CA3 (Mathada et al. 2012).

Anti-inflammatory activity, antipyretic activity, and analgesic

Leaf and flower extracts of $C$. ternatea have been identified as having an inflammatory activity (Devi et al., 2003; Bathia et al., 2013; Suganya et al., 2014; Singh et al., 2018). Petroleum ether extract and ethanol resulted in the analgesic activity that ethanol-treated extract showed up to 2 hours of long-lasting effect (Bathia et al. 2013). Flavonoids were important for anti-inflammatory, analgesic, and antipyretic activities in C. ternatea (Devi et al., 2003). The methanol extract of $C$. ternatea root at 200, 300 , and $400 \mathrm{mg} / \mathrm{kg}$ body weight doses. The yeastprovoked raised the temperature dose-dependent and decreased the temperature body to normal (Parimaladevi et al. 2004). Drugs (narcotics or non-narcotics) treat inflammatory and pain conditions, which are very costly and have adverse effects. Natural drugs, especially from $C$. ternatea, can be an option for providing cheaper and feasible drugs.

\section{Antioxidant activity}

The root extracts of $C$. ternatea have antioxidant activity based on some research both in white flowers and blue flowers (Patil and Patil 2011; Jadhav et al. 2013). Flower extracts of $C$. ternatea have been reported to have antioxidant activity (Kamkaen and Wilkinson 2009; Jayachitra and Padma 2012; Jadhav et al. 2013; Zingare et al. 2013; Azima et al. 2014; Iamsaard et al. 2014; Phrueksanan et al. 2014; Azima et al. 2017; Havananda and Luengwilai 2019; Lakshan et al. 2019). Biological synthesized MgO-NPs of flower extracts of C. ternatea showed high antioxidant activity (Sushma et al. 2016). The white flower produces higher enzyme antioxidants than the blue flower (Jayachitra and Padma 2012). Antioxidant 
activity in $C$. ternatea prevents lipid peroxidation in erythrocytes, protein oxidation, and free radical-induced hemolysis (Phrueksanan et al., 2014). C. ternatea has enzyme and non-enzyme antioxidants rather than the other plants, such as Eclipta prostrata (Rao et al. 2009), Syzygium cumini, and Ardisia colorata (Azima et al. 2017). In addition, Antioxidant activity in $C$. ternatea is potent to be cosmetic properties (Kamkaen and Wilkinson 2009). Currently, the need for natural anti-rising is rising since synthetic antioxidants bring side effects such as allergies, asthma, inflammation, headache, loss of consciousness, and disorders of the eyes and stomach (Sharrmila et al., 2016). C. ternatea has the potential to be used as a natural antioxidant.

\section{Nootropic activity}

Nootropic activity, anxiolytic, anticonvulsant, antistress activity, and antidepressants have been found in the extracts of $C$. ternatea (Jain et al., 2003; Talpate et al. 2014). Root extracts of $C$. ternatea increase acetylcholine in the hippocampus to enhance memory and learning (Rai et al. 2001; Rai et al. 2002). An increase of rat brain acetylcholine and acetylcholinesterase activity was produced from the alcoholic extracts root of $C$. ternatea at $300 \mathrm{mg} / \mathrm{kg}$ doses (Taranalli and Cheeramkuzhy 2000). In addition, $C$. ternatea also raises episodic memory and cellularity and declines autophagy. However, several studies have reported only in experimental animals (rats). This progress is proved that $C$. ternatea has the potential for improvement in human cognitive performance.

\section{AN RELATION BETWEEN ETHNOBOTANY AND BIOPROSPECTING}

There are three critical stimuli to interfere with the community's attitudes, i.e. (i) natural stimulus, (ii) helpful stimulus, and (iii) religious stimulus (Zuhud et al. 2007). The stimuli are a powerful driver of the community's attitude and behavior for realizing conservation actions. Firstly, the natural stimulus is a sustainable resource that needs to be based on bioecology characters. This plant is a wildflower. Even though people also cultivate in the home garden (Eni et al. 2019). Farmers can increase their income and conserve agro-biodiversity through their home gardens (Mohri et al., 2013; Sutoro 2017).

Secondly, the valuable stimulus is the values of humanbeing needs for economic, medicine, biological/ecological, and the other benefits. It can be identified by biological/ecological utilization, medicinal uses, economic sectors, and social culture aspects (Deryanti et al., 2007; Zakiyyah et al., 2016). Exploration knowledge is an initial step to optimize the potential of $C$. ternatea. The study of ethnobotany can be used to analyze the bioprospecting of C. ternatea. Then, further research can continue to produce commercial products to increase income for the community. For example, the information from the ethnobotany of $C$. ternatea in Indonesia describes it as a medicinal plant, some processed products such as herbal tea (dried $C$. ternatea), coloring powder, and eye drops.
Species are endangered or rare because people use natural resources to utilize knowledge or exploit. So, when the valuable stimulus can be optimized, it will empower the community to be part of conservation action. Optimizing bioprospecting can generate income and support the conservation project (Skirycz et al., 2016).

Thirdly, a religious stimulus is noble values, especially the rewards from God, spiritual values, universal religious values, merit, happiness, cultural/traditional wisdom, inner satisfaction, and many more. For instance, a local concept of traditional medicine called "Usada Taru Pramana" in Bali. In the idea, C. ternatea is regarded as a medicinal plant for the eye (Cahyaningsih et al. 2019). Bali communities admit Usada or Aushadhi in Sanskrit as guidance for plant medicine (Sutomo and Iryadi 2019). It is related to the Hindu-Bali's belief, Tri Hita Karana. Tri Hita Karana is the philosophy of harmony relation between human beings and God (parhyangan), harmony with other people (pawongan), and connection with nature (palemahan) (Wirawan and Pendit 2017) (Figure 2). Parhyangan is a value/mindset element that can be described in the existence of the Hindu temple. According to Suarmini (2011), Parhyangan associated with social subsystems is realized by conducting ceremonies on certain days. In these ceremonies, $C$. ternatea is usually used as one of the elements. Pawongan is associated with a social subsystem, where the community has to maintain harmony and togetherness. Palemahan is related to the mindset/value realized in preserving, such as a village, village forest, and nature. Rather than exploiting nature, Palemahan intends to think that nature is an equitable partner.

Based on the three critical stimuli to the effect of community's attitudes, the relation between ethnobotany, bioprospecting, society, and conservation was shown in Figure 3. We modified the circle of regard by adding ethnobotany as a part of values. Since Indonesia is rich in ethnobotany knowledge that can be a source of natural products. In exploration (ethnobotany), species are still known locally and limited. Thus, comprehensive research by government research institutes or private industries is needed for scientifically proven. The result of the study is products that can be promoted to more comprehensive customers. The products can be used as commercial products. Finally, the study should provide an economic impact on the communities and motivate communities to conserve them.

\section{FUTURE OUTLOOK OF MARKET OVERVIEW}

According to the Indonesian Agriculture Ministry Decree Number 511/Kpts/PD.310/9/2020, C. ternatea on kinds of plant commodities fostered by Directorate General of Plantation, Directorate General of Food Crops, and the Directorate General of Horticulture (Indonesian Agriculture Ministry 2020) However, in the market overview, the production of $C$. ternatea products are still not optimal. However, herbal medicine is rising gradually with the "back to nature" trend worldwide (Fernandes et 
al., 2019). In 2019, the traditional medicine industrial sector grew above $6 \%$ or above the national economic growth. Industries absorbed herbal medicine of $63 \%$ total market, then exports by $14 \%$, and for household consumption 23\% in 2007 (Indonesian Agriculture Ministry 2007). In Indonesia, most herbal medicine consumers are economically categorized as the low-middle class (Andriati and Wahjudi 2016).

A qualitative study with descriptive analysis was used to survey the three most significant marketplaces in Indonesia, e.g., Bukalapak (www.bukalapak.com), Tokopedia (www.tokopedia.com), and Shopee (www.shopee.co.id). It aimed to know the diversity of $C$. ternatea in the Indonesian marketplace. We observed the products sold from 100 procedures in each marketplace (Figure 4). Result explicate that $C$. ternatea was mostly sold as a dried flower tea (Tokopedia of 65\%, Bukalapak of $53 \%$, and Shopee of $74 \%$ ) and a commercial seed/seedling (Tokopedia of $22 \%$, Bukalapak $41 \%$, and Shopee 22\%). This result is identical with ethnobotany information which said that the flower of $C$. ternatea is used the most. Less than $10 \%$ of $C$. ternatea was used for beverages. Also, there was a product of eye drops $(1 \%)$. The same percentage of $1 \%$ was used for fresh leaf, flower, and coloring powder. Thus, according to this data, the utilization of $C$. ternatea has still not developed optimally.

The current development of technology eliminates the gap between producers and consumers. Through ecommerce, for instance, it is easier for the farmers to enlarge their market access, increase the sale, and reduce transaction costs (Chang and Just 2009; Mishra et al. 2009; Zapata et al. 2016; Fecke et al. 2018). In January 2020, the total of internet users in Indonesia reached $+175.4 \mathrm{M}$, and this number increased by $+17 \%$ between 2019 and 2020 . That makes Indonesia the top five most significant internet

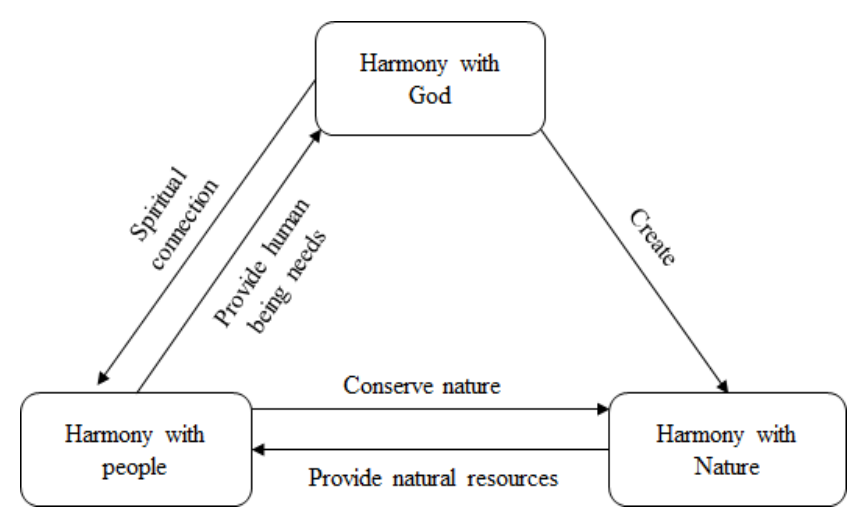

Figure 2. The ancient Balinese philosophy of Tri Hita Karana (Nias Press in Zen et al. 2019) users, with people spending 7 hours 59 minutes longer than globally (Kemp 2020). This condition leads to a shift of consumers' behavior from conventional to digital in their daily activities.

Most producers are small-medium enterprises that use home gardens or limited land and partnership farmers with social enterprises to sell and process their products-for example, empowering farmers through the partnership that Agradaya dan Javara has done. Javara claims to have a partnership with more than 5000 farmers throughout Indonesia and is visioning "to preserve Indonesia's biodiversity and brings community-based, organic products to broader markets" (Javara 2020). On the other hand, Agradaya has a partnership with more than 300 farmers in Yogyakarta and East Java and brings a mission of "collaboration for sustainable agriculture" (Agradaya 2019).

C. ternatea is also grown for urban farming since it can live in various habitat types. For instance, Konekroot is rooftop farming that has hydroponic, aquaponics, and organic agriculture (Konektoot 2019). They sell processing C. ternatea for dried tea or seed/seedling. They also use $C$. ternatea for garnish of food. Besides that, Kebun Kumara, a social enterprise located in Jakarta, grows $C$. ternatea in its urban space for agriculture. Like Konekroot, Kebun Kumar also sells seed/seedling of C. ternatea (Kebun Kumara 2019).

In conclusion, the ethnobotany of $C$. ternatea can be knowledge resources for bioprospecting in several utilizations, such as food and beverage, agriculture, and medicine. Through innovation, technology, and research, the potential of $C$. ternatea can be explored to provide high-quality products under tremendous opportunities. We hope that the study will impact communities' economics and escalate their motivation to conserve $C$. ternatea.

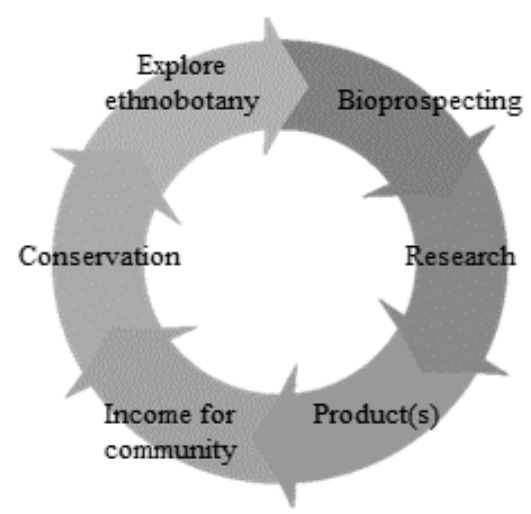

Figure 3. Ideal relation between ethnobotany, bioprospecting, community, and conservation 

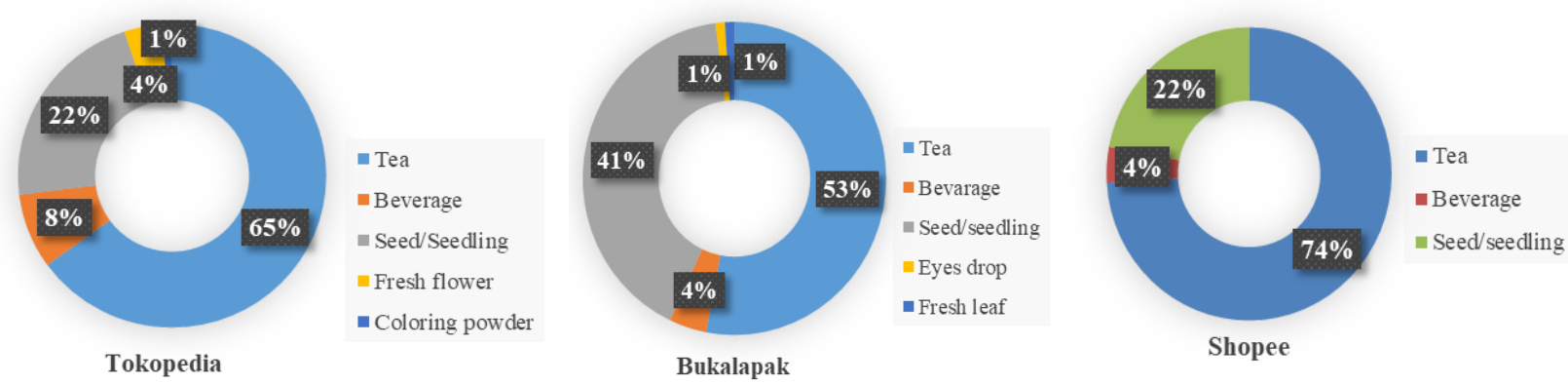

Figure 4. The diversity of products of $C$. ternatea in Indonesia's e-commerce; source: Tokopedia (www.tokopedia.com), Bukalapak (www.bukalapak.com), and Shopee (www.shopee.co.id)

\section{REFERENCES}

Abdelhamid AM, Gabr AA. 1993. The evaluation of new fodder sources (Clitoria and Pillipesara) under Egyptian conditions. Arch Anim Nutr 44: 85-93. DOI: 10.1080/17450399309386060.

Abreu MLC, Vieira RAM, Rocha NS, Araujo RP, Gloria LS, Fernandes AM, de Lacerda PD, Junior AG. 2014. Clitoria ternatea 1. as a potential high quality forage legume. Asian Australas J Anim Sci 27 (2): 169-178. DOI: 10.5713/ajas.2013.13343.

Agradaya. 2019. About Agradaya. Retriveved from https: //www.agradaya.id/

Ajesh K, Sreejith K. 2014. A novel antifungal protein with lysozyme-like activity from seeds of Clitoria ternatea. Appl Biochem Biotechnol 173: 682-693. DOI: 10.1007/s12010-014-0880-8.

Al-Snafi AE. 2016. Pharmacological importance of Clitoria ternatea-A review. IOSR J Pharm 6 (3): 68-83.

Alderete-Chevez A, Guerra-Santos JJ, Cruz-Lander NDL, Brito R, Guevera E, Gelbert R, Nunez E, Endanu E, Amador-del Angel LE. 2011. Evaluation of Clitoria ternatea L. in relation to fertility in tropical soils. J Appl Sci 11 (6): 1044-1048. DOI: 10.3923/jas.2011.1044.1048.

Amanati L. 2014. Staphylococcus Aureus and Bacillus Cereus bacteria test on instant noodle products at the market. Ber Litbang Industri 3 (2): 73-80.

Anand SP, Doss A, Nandagopalan V. 2011. Antibacterial studies on leaves of Clitoria ternatea Linn.-a high potential medicinal plant. Int J Appl Biol Pharm Technol 2 (3): 453-456.

Andriati, Wahjudi RMT. 2016. Society's acceptance level of herb as alternative to modern medicine for lower, middle, and upper-class groups. Masyarakat, Kebud dan Polit 29 (3): 133-145. DOI 10.20473/mkp.V29I32016.133-145

Angriani L. 2019. The potential of extract butterfly pea flower (Clitoria ternatea L.) as a local natural dye for various food industries. Canrea J 2 (1): 32-37.

Anthika B, Kusumacahyo SP, Sutanto H. 2015. Ultrasonic approach in Clitoria ternatea (butterfly pea) extraction in water extract sterilization by ultrafiltration for eye drop active ingredients. Procedia Chem 16: 237-244. DOI: 10.1016/j.proche.2015.12.046.

Avalos JSV, Cardenas JAB, Ceja JVR, Guerrero JJB. 2004. Agrotechnics and use of Clitoria ternatea in beef and milk production systems. Téc Pecu Méx 42 (1): 79-96.

Azima S AM, Noriham A, Manshoor N. 2017. Phenolics, antioxidants, and color properties of aqueous pigmented plant extracts: Ardisia colorata var. elliptica, Clitoria ternatea, Garcinia mangostana, and Syzygium cumini. J Funct Foods 38: 232-241. DOI: 10.1016/j.jff.2017.09.018.

Azima SAM, Noriham A, Manshoor N. 2014. Anthocyanin content in relation to the antioxidant activity and colour properties of Garcinia mangostana peel, Syzygium cumini, and Clitoria ternatea extracts. Intl Food Res J 21 (6): 2369-2375.

Banerjee SK, Chakravarti RN. 1964. Taraxerone from Clitoria ternatea Linn. Bull Calcutta Sch Trop Med 12: 23.

Barro C, Ribeiro A. 1983. The study of Clitoria ternatea L. hay as a forage alternative in tropical countries. Evolution of the chemica composition at four different growth stages. J Sci Food Agric 34: 780782. DOI: $10.1002 /$ jsfa. 2740340803 .

Barros NN, Freire LCL, Lopes EA, Johnson WL. 1991. Comparative study of digestibility of forage legume with sheep and goats. 1: in vivo digestibility of cunha hay. Pesq Agropec Bras 26: 1209-1213.

Bathia M, Chahal J, Gupta S. 2013. Analgesic and anti-inflammatory activities of Clitoria ternatea Linn. leaves extract on rat model. Intl J Pharm Sci Res 5 (2): 600-660.
Beattie AJ, Barthlott W. Elisabetsky E, Farrel R, Kheng CT, Rosenthal JP, Simpson D, Leakey RRB, Wolfson M, Laird S. 2005. New products and industries from biodiversity. Ecosystems and Human Well-Being. In: Hassan R, Scholes R, Ash N (eds). Millennium Ecosystem Assessment. Island Pr., Washington DC.

Bharti S, Kumari D. 2017. Drought stress response in Clitoria ternatea L. Intl J Informative \& Futuristic Res 4 (10): 7932-7940.

Borikar SP, Kallewar NG, Mahapatra DK, Dumore NG. 2018. Dried flower powder combination of Clitoria ternatea and Punica granatum demonstrated analogous anti-hyperglycemic potential as compared with standard drug metformin: In vivo study in Sprague Dawley rats. J Appl Pharm Sci 8 (11): 75-79. DOI: 10.7324/JAPS.2018.81111.

Budi US, Basuki N, Sudjindro. 2006. The resistance character inheritance of root-knot nematode (Meloidogyne incognita) in kenaf (Hibiscus cannabinus L.). Zuriat 17 (1): 60-65. DOI: 10.24198/zuriat.v17i1.6755.

Bukalapak. 2020. Telang. Retriveved from www.bukalapak.com

Cahyaningsih E, Shandi PEK, Santoso P. 2019. Phytochemical screening and antioxidant activity of telang flower extract (Clitoria ternatea L.) using uv-vis spectrophotometry. J Ilm Medicam 5 (1): 51-57. DOI: 10.36733/medicamento.v5i1.851.

Chang HH, Just DR. 2009. Internet access and farm household incomeempirical evidence using a semi-parametric assessment in Taiwan. J Agric Econ 60 (2): 348-366. DOI: 10.1111/j.1477-9552.2008.00189.x.

Chen LH, Chen IC, Chen PY, Huang PH. 2018. Application of butterfly pea flower extract in mask development. Sci Pharm 86 (53): 1-9. DOI: 10.3390/scipharm86040053

Chusak C, Henry C, Chantarasinlapin P, Techasukthavorn V, Adisakwattana S. 2018b. Influence of Clitoria ternatea flower extract on the in vitro enzymatic digestibility of starch and its application in bread. Foods 7 (7): 102. DOI: 10.3390/foods7070102.

Chusak C, Thilavech T, Henry CJ, Adisakwattana S. 2018a. Acute effect of Clitoria ternatea flower beverage on glycemic response and antioxidant capacity in healthy subjects: a randomized crossover trial. BMC Compl Altern Med 18 (1): 1-11. DOI: 10.1186/s12906-017-2075-7.

Chusak C, Ying JAY, Zhien JL, Pasukamonset P, Henry CJ, Ngamukote S, Adisakwattana S. 2019. Impact of Clitoria ternatea (butterfly pea) flower on in vitro starch digestibility, texture, and sensory attributes of cooked rice using domestic cooking methods. Food Chem 295: 646-652. DOI: 10.1016/j.foodchem.2019.05.157

Daisy P, Rajathi M. 2009. Hypoglycemic Effects of Clitoria ternatea Linn. (Fabaceae) in Alloxan-induced Diabetes in Rats. Trop J Pharm Res 8 (5): 393-398. DOI: 10.4314/tjpr.v8i5.48082.

Das AK. 2003. Citrus canker-A review. J Appl Hort 5 (1): 52-60. DOI: 10.37855/jah.2003.v05i01.15.

Das N, Chatterjee P. 2014. Antifungal effect of Clitoria ternatea leaf extract on seeds of Pisum sativum in relation to the activities of some enzymes. Intl J Res Ayurveda Pharm 5: 99-101. DOI: 10.7897/22774343.05120 .

De Souza ES, Burity HA, Olivera J, Figueiredo MVB, de Lyra MDCCP. 1996. N2-fixation and growth of the calopogonium (Calopogonium mucunoides devs.) and of the clitoria (Clitoria ternatea L.) after successive cuts. Rev Bras Zootec 25 (6): 1036-1048.

Defiani MR, Kriswiyanti E. 2019. Floral diversity in Mincidan Village, Klungkung, Bali to support ecotourism. Simbiosis 7 (1): 14-21. DOI: 10.24843/JSIMBIOSIS.2019.v07.i01.p04.

Deryanti T, Zuhud EAM, Soekmadi R. 2007. Conservation of nutmeg (Myristica fragrans Houtt) an analysis of three stimulus amar (natural, use, willing) pro-conservation cases in Bogor Regency. Media Konserv 19 (1): 47-56.

Destryana RA, Ismawati. 2019. Ethnobotany and the use of wild plants as traditional medicine by the Madura Communities (study case in 
Lenteng, Guluk-guluk, and Bluto Districts). J Food Technol Agroindustry 1 (2): 1-8.

Devi BP, Boominathan R, Mandal SC. 2003. Anti-inflammatory, analgesic, and antipyretic properties of Clitoria ternatea root. Fitoterapia 74: 345-349. DOI: $10.1016 / \mathrm{S} 0367-326 \mathrm{X}(03) 00057-1$.

Dewi, AP, Setyawardani T, Sumarmono J. 2019. The Effect of Butterfly Pea (Clitoria ternatea) Addition on Syneresis and Levels of Pleasure of Goat Milk Yoghurt. ANGON: J Anim Sci Technol 1 (2): 145-151.

Dhiman MR, Kumar S, Parkash C, Kumar R, Moudgil S, Sharma S. 2017. Determination of phytochemical and antioxidant activities in edible flowers. Intl J Hortic 7 (4): 26-32. DOI: 10.5376/ijh.2017.07.0004

Diyasti F, Santoso T, Kusumah YM. 2016. Morphology, biology, and molecular characteristics of three isolates of Helicoverpa armigera Nucleopolyhedrovirus (HearNPV) against cotton bollworm, Helicoverpa armigera Hubner (Lepidoptera: Noctuidae). Indones J Entomol 13 (3): 117-126. DOI: 10.5994/jei.13.3.117.

Ekantini PRRI, Mega KT, Prasojo P. 2017. Identification of Bacillus Cereusbacteria on wets noodle in Kebonpolo Market of Magelang. Farm Sains Praktis 3 (1): 1-5.

Elamin KM, Elkhairey MA, Ahmed HB, Musa AM, Bakhiet AO. 2011. Effect of different feeds on performance and some blood constituents of local rabits. Res J Vet Sci 4 (2): 37-42. DOI: 10.3923/rjvs.2011.37.42.

Eni NNS, Sukenti K, Muspiah A, Rohyani IS. 2019. Ethnobotany study of medicinal plants in the Hindu Community of Jagaraga Village, Wes Lombok Regency, West Nusa Tenggara. Biotropika J Trop Biol 7 (3): 121-128. DOI: 10.21776/ub.biotropika.2019.007.03.5

Febrianti BA. 2019. Utilization of anthocyanin pigments from several plants as a natural color in the making of getuk lindri. [Dissertation]. UIN Raden Intan, Lampung. [Indonesian]

Fecke W, Danne M, Musshoff, O. 2018. E-commerce in agriculture-The case of crop protection product purchases in a discrete choice experiment. Comput Electron Agric 151: 126-135. DOI 10.1016/j.compag.2018.05.032.

Fernandes L, Casal S, Pereira JA, Saraiva JA, Ramalhosa E. 2019. An overview on the market of edible flowers. Food Rev Int: 1-18.

Fernandes L, Saraiva JA, Pereira JA, Casal S, Ramalhosa E. 2018. Postharvest technologies applied to edible flowers: a review. Food Rev Intl 36 (3): 1-23. DOI: 10.1080/87559129.2019.1639727.

Gilding EK, Jackson MA, Poth AG, Heriques ST, Prentis PJ, Mahatmo T, Craik DJ. 2015. Gene coevolution and regulation lock cyclic plan defense peptides to their targets. New Phytologist 210 (2): 717-730. DOI: $10.1111 / \mathrm{nph} .13789$

Gillett JB, Polhill RM, Verdcourt B. 1971. Flora of Tropical East Africa, Leguminosae. Crown Agents for Overseas Governments and Administrations, London.

Gomez SM, Kalamani A. 2003. Butterfly pea (Clitoria ternatea): nutritive multipurpose forage legume for tropics-an overview. Pak J Nutr 2 (6): 374-379. DOI: 10.3923/pjn.2003.374.379.

Grindley DN, Burden EHWJ, Akour AA. 1954. The seed oils of Clitoria ternatea and of Entada phaseoloides. J Sci Food Agric 5 (6): 278-280 DOI: $10.1002 /$ jsfa. 2740050605

Gupta GK, Jagbir Chahal J, Bhatia M. 2010. Clitoria ternatea (L.): old and new aspects. J Pharm Res 3 (11): 2610-2614.

Habish HA, Mahdi AA. 1979. Nodulation of Legumes in the Sudan. East $\begin{array}{lllll}\text { African Agric For J } 44 & \text { (3): 229-236. DOI }\end{array}$ 10.1080/00128325.1979.11663013

Hall TJ. 1985. Adaptation and agronomy of Clitoria ternatea L. in Northern Australia. Trop Grassland 19 (4): 156-163.

Hariadi H, Sunyoto M, Nurhadi B, Karuniawan A. 2018. Comparison of phytochemical characteristics pigment extract (Antosianin) sweet purple potatoes powder (Ipomoea batatas L.) and clitoria flower (Clitoria ternatea) as natural dye powder. J Pharma Phytochem 7 (4): 3420-3429.

Hartono, Angelia M. 2013. Utilization of extract butterfly pea flowers (Clitoria ternatea L.) as natural colorant of ice lolly. J Biol: 1-15.

Haryanti ES, Diba F, Wahdina. 2015. Ethnobotany of useful plant society around the Area Model KPH Kapuas Upstream (case study Tamao Village, District Embaloh Hulu West Kalimantan). J Hutan Lestari 3 (3): 434-445

Hasan N, Jain RK. 1985. Preliminary assessment of the response of Clitoria ternatea lines to the root-knot nematode, Meloidogyne Incognita. Nematologica 31: 236-238. DOI: 10.1163/187529285X00319.

Havananda T, Luengwilai K. 2019. Variation in floral antioxidant activities and phytochemical properties among butterfly pea (Clitoric ternatea L.) germplasm. Genet Resour Crop Evol 66: 645-658. DOI 10.1007/s10722-018-00738-6.

Husain S, Devi KS. 1998. Fatty acid composition of three plant species: Clitoria ternatea, Mandulea suberosa and Ruta chalapensis. J Oil Technol Assoc India 30: 162-164
Hutajulu TF, Sari R, Djumarman. 2008. Identification of phenol and delphinidin in the telangs flower (Clitoria ternatea L.) and its effectivity to Staphylococcus aureus as eyes bacterial disease. J AgroBased Ind 25 (2): 35-44

Iamsaard S, Burawat J, Kanla P, Arun S, Sukhorum W, Sripanidkulchai B, Uabundit N, Wattathorn J, Hipkaeo W, Fongmoon D, Kondo H. 2014. Antioxidant activity and protective effect of Clitoria ternatea flower extract on testicular damage induced by ketoconazole in rats. J Zhejiang Univ-Sci B 15 (6): 548-555. DOI: 10.1631/jzus.B1300299.

Indonesian Agriculture Ministry. 2007. Prospect and Directions of Agribusiness Development for Medicinal Plant. Indonesian Agency for Agricultural Research and Development, Bogor.

Indonesian Agriculture Ministry. 2020. Plant commodities fostered by the Directorate General of Plantation, Directorate General of Food Crops, and the Directorate General of Horticulture. Indonesian Agriculture Ministry, Jakarta.

International Diabetes Federation. 2020. IDF Western Pacific members. Retriveved from https: //www.idf.org/our-network/regionsmembers/western-pacific/members/104-indonesia.html

Irmawatie L, Robana RR, Nuraidah N. 2019. Resistance of seven tomato varieties to root-knot nematodes (Meloidogyne spp.) Agrotech. Res. J. 3 (2): 61-68. DOI: 10.20961 /agrotechresj.v3i2.30392.

Ismawati, Destryana RA. 2019. Inventory of wild plant type of traditional medicine Madura Sumenep Communities. Simbiosis 7 (2): 37-43. DOI: 10.24843/JSIMBIOSIS.2019.v07.i02.p04.

Jadhav V, Deshmukh S, Mahadkar S. 2013. Evaluation of the antioxidant potential of Clitoria ternatea L. Intl J Pharm Pharm Sci 5 (2): 595599

Jain NN, Ohal CC, Shroff SK, Bhutada RH, Somani RS, Kasture VS, Kasture SB. 2003. Clitoria ternatea and the CNS. Pharmacol Biochem Behav 75 (3): 529-536. DOI: 10.1016/S0091-3057(03)00130-8.

Jamil N, Zairi MNM, Nasim NAM, Pa'ee F. 2018. Influences of Environmental Conditions to Phytoconstituents in Clitoria ternatea (Butterfly Pea Flower)-A Review. J Sci Technol 10 (2): 208-228. DOI: $10.30880 /$ jst.2018.10.02.029

Javara. 2020. About Javara. Retriveved from https: //javara.co.id/

Jayachitra A, Padma PR. 2012. Antioxidant potential of Clitoria ternatea leaf extract in vitro. Intl J Pharm Bio Sci 3 (4): 753-763.

Jayani DH. 2019. How Many People Use the Internet?Retrieved from https: //databoks.katadata.co.id/datapublish/2019/09/09/berapapengguna-internet-di-indonesia.

Joshi SS, Shrivastava RK, Shrivastava DK. 1981. Chemical examination of Clitoria ternatea seeds. J Am Oil Chem Soc 58 (6): 714.DOI: 10.1007/BF02899459.

Juma HK, Abdulrazak SA, Muinga RW, Ambula MK. 2006. Evaluation of Clitoria, Gliricidia, and Mucuna as nitrogen supplements to Napier grass basal diet in relation to performance of lactating Jersey cows. Livest Sci 103: 23-29. DOI: 10.1016/j.livsci.2005.12.006.

Kamila L, Mnsor SM, Ramanathan S, Sasidharan S. 2009. Antimicrobial activity of Clitoria ternatea (L.) extracts. Pharm online 1: 731-738

Kamkaen N, Wilkinson JM. 2009. The antioxidant activity of Clitoria ternatea flower petal extracts and eye gel. Phytother Res 23: 16241625. DOI: $10.1002 / \mathrm{ptr} .2832$

Karel A, Kumar H, Chowdhary B. 2018. Clitoria ternatea L. a miraculous plant. Intl J Curr Microbiol Appl Sci 7 (9): 1-4. DOI: 10.20546/ijcmas.2018.709.079.

Kavitha R. 2018. Biochemical studies on the effect of ethanolic extracts of Trichosanthes dioica and Clitoria ternatea in streptozotocin-induced diabetic male Wistar rats. Intl J Pharm Sci Res 9 (11): 4682-4689.

Kazuma K, Kogawa K, Noda N, Kato N, Suzuki M. 2004. Identification of delphinidin 3-O-(6-O-malonyl)--glucoside-3-O--glucoside, a postulated intermediate in the biosynthesis of ternatin C5 in the blue petals of Clitoria ternatea (butterfly pea). Chem Biodivers 1: 17621770. DOI: $10.1002 / \mathrm{cbdv} .200490132$.

Kazuma K, Noda N, Suzuki M. 2003b. Flavonoid composition related to petal color in different lines of Clitoria ternatea. Phytochem 64: 1133-1139. DOI: 10.1016/S0031-9422(03)00504-1.

Kazuma K, Noda N. Suzuki M. 2003a. Malonylated flavonol glycosides from the petals of Clitoria ternatea. Phytochem 62: 229-237. DOI: 10.1016/S0031-9422(02)00486-7.

Kebun Kumara. 2019. About us. Retriveved from https: //www.kebunkumara.id/

Kelemu S, Cardona C, Segura G. 2004. Antimicrobial and insecticidal protein isolated from seeds of Clitoria ternatea, tropical forage legume. Plant Physiol Biochem 42: 867-873. DOI: 10.1016/j.plaphy.2004.10.013.

Kemp S. 2020. Digital 2020: Global Digital Overview. In Global Digital Insights. Retrieved from https: //datareportal.com/reports/digital2020-global-digital-overview.

Khaeruni A, Tjahjono B, Suswanto A, Sinaga MS. 2007. Rapid detection of bacterial pustule disease on soybean employing PCR technique 
with specific primers. Hayati J Biosci 14 (2): 76-80. DOI: 10.4308/hjb.14.2.76

Khaeruni A, Tjahjono B, Suswanto A, Sinaga MS. 2008. Virulence of some Xanthomonas axonopodis pv. glycines Isolates from Edamame on three soybean varieties. J. Hama dan Penyakit Tumbuhan Trop 8 (1): 39-46. DOI: 10.23960/j.hptt.1839-46.

Konekroot. 2019. The importance of urban food. Retriveved from https: //konekroot.com/

Kulshrestha DK, Khare MP, 1967. Chemical investigation of the seeds of Clitoria ternatea. Curr Sci 36: 124-125.

Kulshrestha DK, Khare MP. 1968. Chemical study of Clitoria ternatea seeds. Chemische Berichte 101: 2096-2105. DOI $10.1002 /$ cber.19681010627.

Kumar V, Mukherjee K, Kumar S, Mal M, Mukherjee PK. 2008. Validation of HPTLC method for the analysis of taraxerol in Clitoria ternatea. Phytochem Anal 19: 244-250. DOI: 10.1002/pca.1042.

Kumari NV. Devi ML. 2013. Effect of some indigenous plant extracts on the inhibition of egg hatching of nematode Meloidogyne incognito Chitwood infesting mulberry. Hort Flor Res Spec 2: 35-39.

Kusrini E, Tristantini D, Izza N. 2017. Activity test of telang flower extract (Clitoria ternatea $\mathrm{L}$.) as an anti-cataract agent. J Jamu Indones 2 (1): 30-36. DOI: $10.29244 /$ jii.v2i1.28.

Kusuma AD. 2019. The potential of telang flower tea (Clitoria ternatea) as a medicinal herbal of phlegm thinner through a mucosity test Resenologi 4 (2): 13-19. DOI: 10.47028/j.risenologi.2019.42.53.

Lakshan SAT, Jayanath NY, Abeysekera WPKM, Abeysekera WKSM 2019. A commercial potential blue pea (Clitoria ternatea L.) flowe extract incorporated beverage having functional properties. EvidBased Compl Altern Med 2019 (3): 1-13. DOI: 10.1155/2019/2916914.

Macedo MLR, Xavier-Filho J. 1992. Purification and partial characterisation of trypsin inhibitors from seeds of Clitoria ternatea. J Sci Food Agric 58 (1): 55-58. DOI: 10.1002/jsfa.2740580110.

Mahala AG, Amasiab SO, Yousif MA, Elsadig A. 2012. Effect of plant age on $\mathrm{dm}$ yield and nutritive value of some leguminous plants (Cyamopsis tetragonoloba, Lablab purpureus and Clitoria (Clitoria ternatea). Intl Res J Agric Sci Soil Sci 2 (12): 502-508.

Manjula P, Mohan CH, Sreekanth D, Keerthi B, Devi BP. 2013. Phytochemical analysis of Clitoria ternatea Linn., a valuable medicinal plant. J Indian Bot Soc 92 (3\&4): 173-178.

Marin A, Carias D, Maria CA, Hevia P. 2003. Nutritive value of leaves of Musa paradisiaca and Clitoria ternatea as diluents in diets for broilers. Interciencia 28: 5156.

Mathada RV, Jevoor PS, Ravishankar R. 2012. Effect of Clitoria ternatea linn plant root extract on the hippocampal area $\mathrm{Ca} 3$ and pancreas of juvenile diabetic rats-A preliminary investigation. Spatulla DD 2 (1) 9-16. DOI: $10.5455 /$ spatula.20120119052120.

Mensah R, Leach D, Young A, Watts N, Glennie P. 2015. Development of Clitoria ternatea as a biopesticide for cotton pest management: assessment of product effect on Helicoverpa spp. and their natura enemies. Entomol Exp Appl 154: 131-145. DOI: 10.1111/eea.12263.

Mishra AK, Williams RP, Detre JD. 2009. Internet access and internet purchasing patterns of farm households. Agricultural and Resource Econ Rev 38 (2): 240-257. DOI: 10.1017/S1068280500003233.

Mohri H, Lahoti S, Saito O, Mahalingam A, Gunatilleke N, Irham, Hoang VT, Hitinayake G, Takeuchi K, Herath S. 2013. Assessment of ecosystem services in home garden systems in Indonesia, Sri Lanka, and Vietnam. Ecosyst Serv 5: 124-136. DOI: 10.1016/j.ecoser.2013.07.006.

Monforte J, Carías D, Cioccia AM, Hevia P. 2002. Nutritional value of Clitoria ternatea and Brachiaria humidicola meals in broiler feeding. Interciencia 27: 33-38

Morita N, Arisawa M, Nagase M, Hsu H, Chen Y. 1977. Studies on the constituents of Formosan Leguminosae. I.: The constituents in the leaves of Clitoria ternatea L. Yakugaku Zasshi 97 (6): 649-653. DOI: 10.1248/yakushi1947.97.6_649.

Muir JP, Massaete ES. 1996. Seasonal growth in rabbits fed wheat and maize bran with tropical forages. Livest Res Rural Dev 8 (1).

Mukherjee PK, Kumar V, Kumar NS, Heinrich M. 2008. The Ayurvedic medicine Clitoria ternatea-From traditional use to scientific assessment. J Ethnopharmacol 120 (3): 291-301. DOI: 10.1016/j.jep.2008.09.009

Mukherjee PK, Wahile A. 2006. Integrated approaches towards drug development from Ayurveda and other Indian systems of medicines. J Ethnopharmacol 103: 25-35. DOI: 10.1016/j.jep.2005.09.024.

Mulangsari DAK. 2019. Training to make dried telang flowers as tea brewing in Putra Baiti Jannati Orphanage. Abdimas Unwahas 4 (2) 93-96.

Nguyen GKT, Zhang S, Ngan TKN, Phuong QTN, Chiu MS, Hardjojo A Tam JP. 2011. Discovery and characterization of novel cyclotides originated from chimeric precursors consisting of albumin-1 chain and cyclotide domains in the Fabaceae family. J Biol Chem 286, 24275-24287. DOI: 10.1074/jbc.M111.229922.

Nguyen KN, Nguyen GK, Nguyen PQ, Ang KH, Dedon PC, Tam JP. 2016. Immunostimulating and gram-negative-specific antibacterial cyclotides from the butterfly pea (Clitoria ternatea). FEBS J 283: 2067-2090. DOI: 10.1111/febs.13720.

Njunie MN, Wagger, MG, and Luna-Orea P. 2004. Residue decomposition and nutrient release dynamics from two tropical forage legumes in a Kenyan environment. Agron J 96: 1073-1081. DOI: 10.2134/agronj2004.1073.

Nunik J. 2009. Butterfly pea (Clitoria ternatea) as an herbaceous legume alternative for the integrated farming system of cattle and maize in Timor Island. Wartazoa 19 (1): 43-51.

Oguis GK, Gilding EK, Jackson MA, Craik DJ. 2019. Butterfly pea (Clitoria ternatea), a cyclotide-bearing plant with applications in agriculture and medicine. Front Plant Sci 10: 1-23. DOI: 10.3389/fpls.2019.00645.

Oktavia GAE, Darma IDP, Sujarwo W. 2019. Ethnobotanical study of medicinal plants in the Area Around Buyan-Tamblingan. Bul Kebun Raya 20 (1): 1-16.

Palimbong S, Pariama AS. 2020. Potential of telang flower extract (Clitoria ternatea Linn) as a colorant on sticky rice tapai products. J Sains dan Kesehat 2 (3): 228-235.

Panda S. 2018. A mini-review on non-caffeinated blue tea. Intl J Innov Res Eng Multidiscip Phys Sci 6 (4): 710-713.

Parimaladevi B, Boominathan R, Mandal SC. 2004. Evaluation of antipyretic potential of Clitoria ternatea L. extracts in rats. Phytomedicine 11: 323-326. DOI: 10.1078/0944711041495191.

Patil AP, Patil VR. 2011. Comparative evaluation of in vitro antioxidant activity of root of blue and white flowered varieties of Clitoria ternatea Linn. Intl J Pharmacol 7 (4): 485-491. DOI: 10.3923/ijp.2011.485.491.

Permana MAW. 2019. The development of natural dye from butterfly pea candy products [Dissertation]. Universitas Pendidikan Indonesia, Bandung. [Indonesian].

Petrova I, Petkova N, Inanov I. 2016. Five edible flowers-valuable sources of antioxidants in human nutrition. Intl J Pharmacogn Phytochem Res 8 (4): 604-610

Phrueksanan W, Yibchok-anun S, Adisakwattana. 2014. Protection of Clitoria ternatea flower petal extract against free radical-induced hemolysis and oxidative damage in canine erythrocytes. Res Vet Sci 97 (2): 357-363. DOI: 10.1016/j.rvsc.2014.08.010. DOI: $10.1073 /$ pnas. 1103660108

Poth AG, Colgrave ML, Lyons RE, Daly NL, and Craik DJ. 2011. Discovery of an unusual biosynthetic origin for circular proteins in legumes. Proc Natl Acad Sci USA 108: 10127-10132.

Pradana AP, Munif A, Supramana. 2016. Endophytic bacteria from the root of several plants as biocontrol agents of the root-knot nematode Meloidogyne incognita on tomato. J Fitopatol Indones 12 (3): 75-82. DOI: $10.14692 /$ jfi.12.3.75

Pratimasari D, Lindawati NY. 2018. The optimization of butterfly pea (Clitoria ternatea) as a natural dye for paracetamol syrup. J Fitopatol Indones J Ilm Manuntung 4 (2): 89-97. DOI: 10.51352/jim.v4i2.187.

Pushpangadan P, George V, Ijlnu TP, Chithra A. 2018. Biodiversity, bioprospecting, traditional knowledge, sustainable development, and value-added products: A review. J Tradit Med Clin Natur 7 (1): 1-7. DOI: $10.4172 / 2573-4555.1000256$.

Rai K, Murthy K, Karanth K, Nalini K, Rao M, Srinivasan K. 2002. Clitoria ternatea root extract enhances acetylcholine content in rat hippocampus. Fitoterapia 73 (7-8): 685-689. DOI: 10.1016/S0367$326 \mathrm{X}(02) 00249-6$

Rai KS, Murthy KD, Karanth KS, Nalini K, Rao MS, Srinivasan KK. 2001. Clitoria ternatea (Linn) root extract treatment during the growth spurt period enhances learning and memory in rats. Indian $\mathrm{J}$ Physiol Pharmacol 45 (3): 305-313.

Rajagopalan N.1964. Free amino acids and amides in legume root nodules. Curr Sci 33: 454-456.

Rao DB, Kiran CR, Madhavi Y, Rao PK, Rao TR. 2009. Evaluation of the antioxidant potential of Clitoria ternatea L. and Eclipta prostrata L. Indian J Biochem Biophys 46: 247-252.

Revilleza MJR, Mendoza EMT, Raymundo LC. 1990. Oligosaccharides in several Philippine indigenous food legumes: Determination, localization, and removal. Plant Foods Hum Nutr 40 (1): 83-93. DOI: $10.1007 / \mathrm{BF} 02193782$

Rike N, Nita ST, Sungkalang C. 2018. Ethnobotany of plant food in Dayak tamambaloh community, west Kalimantan, Indonesia. Intl J Acad Res Dev 3 (3): 267-273

Riyanto EF, Nurjanah AN, Suharti SNI. 2019. Inhibition of ethanol extract of butterfly pea flower (Clitoria ternatea L.) against fooddestroying bacteria. J Kesehat Bakti Tunas Husada J Ilmu-ilmu 
Keperawatan, Anal Kesehat dan Farm 19 (2): 218-225. DOI 10.36465/jkbth.v19i2.500.

Ruriani E, Nurhayati. 2010. Investigation of Bacillus cereus and Salmonella in fried rice sold by street vendor around campus. Agrotek 4 (1): 68-75.

Saati EA, Mulandari RD, Wachid M, Winarsih S. 2018. The utilization of telang flower as healthy-natural food coloring on dawet drink. the 4th International Symposium on Applied Chemistry 2018. Banteng, 1-2 November 2018. [Indonesian]. DOI: 10.1063/1.5064356.

Sandoval B, Valencia E, Rodriguez AA, Randel PF. 2009. Voluntary intake and digestibility of guineagrass (Panicum maximum, Jacq.)clitoria (Clitoria ternatea L Dne.) hay and rhodesgrass (Chloris gayana, Kunth) cv. Callide hay fed to sheep. J Agr UPR 93 (1-2): 4150 .

Sardiana IK, Dinata KK. 2010. The study of the plants use in spiritual activities (upakara) by Balinese Hindu. J Bumi Lestari 10 (1): 123-127.

Schlink AC. 1998. Nutritional value of Clitoria ternatea for sheep in the dry tropics. Proc Aust Soc Anim Prod 22: 361.

Shahid M, Shahzad A, Anis M. 2009. Antibacterial potential of the extracts derived from leaves and in vitro raised calli of medicinal plants Pterocarpus marsupium Roxb., Clitoria ternatea L., and Sans Aveiro Cylindrica Bojer, Ex Hook. Orient Pharm Exp Med 9: 174181. DOI: 10.3742/OPEM.2009.9.2.174.

Shamnad J. 2019. Mineral and nutritional potential of Clitoria ternatea L. variants as forage. J Trop Agric 57 (2): 163-166

Sharmila G, Nikitha VS, Ilaiyarasi S, Dhivya K, Rajasekar V, Kumar N.M, Muthukumaran K, Muthukumaran C. 2016. Ultrasound-assisted extraction of total phenolics from Cassia auriculata leaves and evaluation of its antioxidant activities. Ind Crops Prod 84: 13-21. DOI: 10.1016/j.indcrop.2016.01.010.

Shofi M, Putri MP. 2020. Training on making cendol starch using blue natural dyes extracted from telang flower essence. J Commun Serv Empower 1 (1): 25-30. DOI: 0.22219/jcse.v1i1.11514

Shopee. 2020. Telang. Retriveved from www.shopee.co.id

Singh NK, Garabadu D, Sharma P, Shrivasta SK, Mishra P. 2018. Antiallergy and anti-tussive activity of Clitoria ternatea L. in experimental animals. J Ethnopharmacol 224: 15-26. DOI: 10.1016/j.jep.2018.05.026.

Skirycz A, Kierszniowska S, Meret M, Willmitzer L, Tzotzos G. 2016 Medicinal Bioprospecting of the Amazon Rainforest: A modern Eldorado?. Trends Biotechnol 34 (10): 782-790. DOI 10.1016/j.tibtech.2016.03.006

Srichalkul B. 2018. Ultrasonication extraction, bioactivity, antioxidant activity, total flavonoid, total phenolic, and antioxidant of Clitoria Ternatea Linn flower extract for an anti-aging drink. Pharmacogn Mag 14 (56): 322-327. DOI: 10.4103/pm.pm_206_17.

Srivastava BK, Pande ES. 1977. Anthocyanins from the flower of Clitoria ternatea. Planta Med 32: 138-140. DOI: 10.1055/s-0028-1097573.

Staples IB. 1992. "Clitoria ternatea L," in Plant Resources of Southeas Asia. Pudoc Scientific Pub, Wageningen.

Suarmini NW. 2011. The role of Pakraman Village in strengthening sociocultural resilience through the knowledge concept of "Tri Hita Karana" J Sos Hum 4 (1): 1-12. DOI: 10.12962/j24433527.v4i1.635.

Suarna IW. 2005. Butterfly pea (Clitoria ternatea) as a forage and cover crops. In: Subandriyo, Diwyanto K, Inounu I, Prawiradiputra BR Setiadi B, Nurhayati, Priyanti A, (eds). Lokakarya Nasional Tanaman Pakan Ternak. Bogor, 16 September 2005. [Indonesian].

Suganda T, Adhi SR. 2017. Preliminary study on the fungicidal effect of butterfly pea flower (Clitoria ternatea L.) against Fusarium oxysporum f.sp. cepae, the causal agent of moler diseases on shallot. J Agrikultura 28 (3): 136-140. DOI: 10.24198/agrikultura.v28i3.15746.

Suganya G, Sampath KP, Dheeba B, Sivakumar R. 2014. In vitro antidiabetic, the antioxidant and anti-inflammatory activity of Clitoria ternatea L. Intl J Pharm Pharm Sci 6: 342-347.

Sukanaya W. 2001. Resistance of soybean high yielding varieties against root-knot nematode (Meloidogyne incognita). J Perlindungan Tanam Indones 7 (1): 42-48.

Sulistiyowati N. 2016. The Traditional Knowledge of the Dayak Tamambaloh Tribe In Wildlife Hunting In Embaloh Hulu District, Kapuas Hulu Regency, West Kalimantan. [Hon. Thesis]. Universitas Gadjah Mada, Yogyakarta. [Indonesia].

Supiandi MI, Leliavia. 2019. Analysis of natural disasters knowledge in the Dayak Tamambaloh Tribe. J Biosilampari 1 (2): 45-50. DOI 10.31540/biosilampari.v1i2.212.

Surata IK, Gata IW, Sudiana IM. 2015. Ethnobotany study of Balinese Hindu ceremonial plants as an effort to preserve traditional knowledge. J Kaji Bali 5 (2): 265-284.
Suryanti, Hadisutrisno B, Mulaydi, Widada J. 2017. Interaction of Meloidogyne incognita and Fusarium solani on pepper yellowing disease. J Perlindungan Tanam Indones 21 (2): 127-134. DOI: 10.22146/jpti.29760.

Sushma NJ, Prathyusha D, Swathi G, Madhavi T, Raju BDP, Mallikarjuna K, Kim HS. 2016. Facile approach to synthesize magnesium oxide nanoparticles by using Clitoria ternatea-characterization and in vitro antioxidant studies. Appl Nanosci 6: 437-444. DOI: 10.1007/s13204015-0455-1.

Sutedi E. 2013. Potential of butterfly pea (Clitoria ternatea) as a forage. Wartazoa 23 (2): 51-62. DOI: 10.14334/wartazoa.v23i2.715.

Sutomo, Iryadi R. 2019. Conservation of traditional medicinal plants "Usada Bali". Bul Udayana Mengabdi 18 (9): 58-63. DOI: 10.24843/BUM.2019.v18.i04.p11

Sutoro. 2017. Utilization and conservation of food crop genetic diversity in home gardens. Iptek Tanam Pangan 12 (2): 105-112.

Swain SS, Rout KK, Chand PK. 2012. Production of triterpenoid anticancer compound taraxerol in agrobacterium-transformed root cultures of butterfly pea (Clitoria ternatea L.). Appl Biochem Biotechnol 168 (3): 487-503. DOI: 10.1007/s12010-012-9791-8.

Tabeo DF, Ibrahim N, Nugrahani AW. 2019. Ethnobotany of the Togian Tribe on Malenge Island, Talatako District, Tojo Una-una Regency, Central Sulawesi. Biocelebes 13 (1): 31-37.

Talpae KA, Bhosale UA, Zambare MR, Somani R. 2014. Antihyperglycemic and antioxidant activity of Clitoria ternatea Linn. on streptozotocin-induced diabetic rats. Ayu J 34 (4): 433-439. DOI: 10.4103/0974-8520.127730

Taranalli AD, Cheeramkuzhy TC. 2000. Influence of Clitoria Ternatea extracts on memory and central cholinergic activity in rats. Pharm Biol 38 (1): 51-56. DOI: 10.1076/1388-0209(200001)3811-BFT051.

Thakur AV, Ambwani S, Ambwani TK, Ahmad AH, Rawat DS. 2018. Evaluation of phytochemicals in the leaf extract of Clitoria ternatea Willd. through GC-MS analysis. Trop Plant Res 5 (2): 200-206. DOI: 10.22271/tpr.2018.v5.i2.025.

Tiwari RD, Gupta RK. 1959. Chemical examination of the leaves of Clitoria ternatea. J Indian Chem Soc 36: 243-246.

Tokopedia. 2020. Telang. Retriveved from www.tokopedia.com

Vasisht K, Dhobi M, Khullar S, Mandal SK, Karan M. 2016. Norneolignans from the roots of Clitoria ternatea L. Tetrahedron Lett 57: 1758-1762. DOI: 10.1016/j.tetlet.2016.03.024.

Wang F, Miao M, Xia H, Yang L, Wang S, Sun G. 2017. Antioxidant activities of aqueous extracts from 12 Chinese edible flowers in vitro and in vivo. Food Nut Res 61 (1): 1-9. DOI: 10.1080/16546628.2017.1265324

Wirawan IGNPD, Pendit IMR. 2017. The application of Tri Hita Karana in the harmonization of conservation and culture in the tourist attractions in the Bali Botanic Garden. JUMPA 4 (1): 18-32.

Zakiyyah, Zuhud EAM, Sumardjo. 2016. Community's attitudes and conservation a case stimulus of vegetable fern in Desa Gunung Bunder II, District of Pamijahan, Bogor. J Nat Resour Environ Manag 6 (1): 71-76. DOI: 10.19081/jpsl.6.1.71.

Zapata SD, Massa OI, Carpio CE, Lamie RD. 2016. Does e-commerce help farmers' markets? measuring the impact of market maker. J Food Distrib Res 47 (2): 1-18

Zaroug MG, Munns DN. 1980b. Effects of phosphorus and sulfur nutrition on soluble sugars and growth in Clitoria ternatea L. Plant Soil 55: 243-250. DOI: 10.1007/BF02181804.

Zaroug, MG, Munns DN. 1980a. Screening strains of Rhizobium for the tropical legumes Clitoria ternatea and Vigna trilobata in soils of different $\mathrm{pH}$. Trop Grasslands 14: 28-33.

Zen IS, Purwanto Y, Titisari PW, Hendrayani Y, Ariffin SAIBS. 2019. Take stock of Bali island as the potential of biosphere reserve site. The 2018 International Conference on Biosphere Reserve: The Role of Stakeholders in Mainstreaming Natural Resources Related to Agenda 2030 (Sustainable Development Goals). Palembang, South Sumatera, 23 July 2018. [Indonesian].

Zingare ML, Zingare PL, Dubey AK, Ansari MA. 2013. Clitoria ternatea (aparajita): a review of the antioxidant, antidiabetic and hepatoprotective potentials. Intl J Pharm Biol Sci 3 (1): 203-2013.

Zuhud EAM, Sofyan K, Prassetyo LB, Kartodihardjo H. 2007. Community's attitudes and conservation: an analysis of kedawung (Parkia timoriana (DC.) Merr.), stimulus of medicinal plant for the community, case in Meru Betiri National Park. Media Konserv 7: 22-32.

Zussiva AM, Laurent BK, Budiyati S. 2012. Extraction and analysis of blue dye (Anthocyanin) from butterfly pea (Clitoria ternatea) as a natural dye. J Teknol Kim Ind 1 (1): 356-365. 